\title{
Corporate Board and Upper Echelons: The Case of the American Most Admired Firms
}

\author{
Karima Dhaouadi ${ }^{1}$ \\ ${ }^{1}$ Higher Institute of Accounting and Business Administration, Tunisia \\ Correspondence: Karima Dhaouadi, Higher Institute of Accounting and Business Administration, Tunisia. E-mail: \\ dkarima76@yahoo.fr
}

Received: December 20, 2017

Accepted: February 7, 2018

Online Published: March 18, 2018

doi:10.5539/ijbm.v13n4p245

URL: https://doi.org/10.5539/ijbm.v13n4p245

\begin{abstract}
The purpose of the paper is to study the effect of board effectiveness on the Top Management Team demographic characteristics of 274 American firms. The research mobilizes theoretically the upper echelons, the agency and the cognitive theories and empirically the clustering and the discriminating analysis. The results indicate that the TMT demographic attributes are not tied systematically to the board efficiency according to contractual approach of corporate governance. The relationship between the board characteristics and the TMT traits is not linear. The study contributes to corporate governance knowledge by highlighting the strategic role of the boards dealing with the TMT choice.
\end{abstract}

Keywords: board of directors, top management team, cognitive theory, clustering and discriminating analysis

JEL codes: G34; J82; G41; C38.

\section{Introduction}

The main purpose of the present paper is to study the effect of firms' governance (composition of the board of directors and ownership structure of firms) on their human capital.

To measure the human capital, the demographic attributes of Top Management Team (TMT) are used as indicators of the managers' experience in accordance with the "Upper Echelons" theory of Hambrick and Mason (1984) and like a multitude of previous works (Beckman et al., 2007; Beckman and Burton, 2008; Certo et al., 2006; Jaw and Lin, 2000; Hitt et al., 2006). In this regard, the TMT demographic characteristics can be perceived as proxies of qualification. They can be also considered as power and entrenchment vehicles (entrenchment theory). The TMT is the most dominant coalition in the firm. It is the group of top executives with overall responsibility for the organization (Finkelstein et al., 2009). In our research, it contains the five best paid managers.

The current work will investigate two main perspectives of corporate governance in the Human Capital field: these are especially the contractual and the cognitive approaches. We seek to investigate the determinants of TMT attributes. The study attempts to test the effectiveness of the governance mechanisms in the TMT choice and the limitation of the managers' entrenchment. To do this, we will deploy the clustering and the discriminating analysis.

Our study differs from the precedent works because it contemplates the TMT attributes and not only of the CEO ones. Also, it links two themes belonging to different fields (Human Resource Management and Corporate Finance). In the one hand, the Human Capital is the stock of competencies, knowledge and personality attributes embodied in the ability to perform labor so as to produce economic value.

On the other hand, Corporate Governance includes the relationships among the stakeholders involved and the goals for which the corporation is governed. It is intended to increase the confidence of shareholders and capital-market investors and it try to decrease the principal-agent problem. At this regard, the board of directors is expected to play a key role in monitoring managers. The board has a fiduciary duty of appointing the CEO. Also it may use its formal and informal power to fire the whole managerial coalition. So we can deduct clearly that the board composition should has an impact on the TMT characteristics. Therefore, it is expected that the boards which are conform to the instructions of the good governance tend to limit the power of managers by nominating young, recent and heterogeneous TMT (according to the contractual approach). 
Over the latter years, there is a renewed interest in the governance and the human capital issues. The importance of our problematic comes from the emergence of new theories in corporate governance after the succession of several financial scandals since the Enron affair in 2001 (Arthur Anderson, Tyco, World Com, Xerox...). The collapses of the Anglo-Saxon model of governance and the increase of irregularities and fraud have renewed the interest of the public and the media to the governance issue (Laszlo et al., 2015; Taylor, 2003)

Furthermore, the human capital is a major concern of the economic world. Nowadays, this subject draws the attention of the researchers and the practitioners' community (Finkelstein el al, 2009; Marvel et al., 2016). We know well that the intangible capital became today the main source of the firms' competitiveness and the human capital is an integral part of the intangible capital (Bontis, 1998).

Our research investigates two themes which are topical and in vogue: human capital and corporate governance. Also, the paper envisages the main dominant coalitions in the firms: which are the TMT and the board of directors. In addition, it has the merit of going beyond the classical approach of agency in order to elucidate the arguments of the strategic and the cognitive perspective.

The paper will be divided into three sections. The first will present the hypotheses to be tested which are based on the theoretical arguments of different approaches of governance. The second will be devoted to the description of the research models and the results which will be the subject of a detailed interpretation in the last section.

\section{Literature Review and Hypothesis}

\subsection{Board of Directors: A Key Internal Mechanism of Corporate Governance}

The Corporate Governance objective is to establish systems that delimit the decision-making power of the top managers. The theoretical framework of governance found its origin mainly in the works of Alchian and Demsetz (1972), Jensen and Meckling (1976), Fama (1980), Williamsson (1985) and Shleifer and Vishny (1986). The major agency assumptions underlying to the governance theory argue that the managers have a tendency to pursue their self interests (enhancing compensation and power). Also, they benefit from the asymmetry of information to develop entrenchment strategies and they are risk and effort averse.

Given the opportunistic managerial behavior, multiple mechanisms of control have been suggested by the Corporate Governance. Among these mechanisms, the board of directors is the most well known. It is an intentional and internal mechanism. It is supposed to play a relevant role. It should participate in the strategic decisions and ensure the transparency. Also, its main mission is to evaluate the performance, hire and fire the TMT: Hence the link between the board and the Upper Echelons. Thus, the TMT attributes seem to depend on the boards' characteristics.

\subsection{Upper Echelons Theory: Our Main Theoretical Reference in the Human Capital Field}

The use of the Human Capital term in the modern neoclassical economic literature dates back to Mincer's article "Investment in Human Capital and Personal Income Distribution" in The Journal of Political Economy in 1958. The best-known application is that of Becker. His book entitled Human Capital, published in 1964, became a standard reference for many years. The Human Capital reflects the employees' competence, skills, knowledge and abilities.

The importance of the Human Capital is stressed by the economists (Palacios, 2015; Rumberger, 1987; Tsang, 1987), the Resource-Based Theory (Barney, 1991; Daily et al., 2000; Finkelstein and Hambrick, 1996; Peterson et al., 2003) and the Human Resource Management (Hogan and Kaiser, 2005; Karamiet al., 2006). The Human Capital has gained in importance since the organizational knowledge has become the most critical ingredient in maintaining a solid competitive advantage in this new era of modern economy ("Knowledge Based Theory").

The researches in the framework of the Human Capital field have insisted on the active role of TMT (Buyl et al., 2011; Carpenter et al., 2004; Mihalache et al., 2014). In effect, the TMT are supposed to establish firms' strategy, detect environmental opportunities and threats, stimulate progress and create value. In the vein of these ideas, the work of Hambrick and Mason (1984) seems to be the most well known. This study has established the "Upper Echelons Theory" and has demonstrated the effect of TMT demographic characteristics on firms' performance. It is frequently used since it is based on objective and rich indicators. The figure 1 shows the reasoning of the Upper Echelons' theory. 


\begin{tabular}{|lll|}
\hline Firms' competitiveness $\longleftarrow$ Organizational Decisions & TMT Perceptions \\
TMT Demographic Characteristics $\rightarrow$ TMT Experience & $\longrightarrow$ TMT Cognitive Base \\
\hline
\end{tabular}

Figure 1. Upper Echelons’ theory thread (Hambrick \& Mason, 1984)

In this respect, the TMT age and tenure are the most relevant indicators (Hitt et al., 2006). They reflect at the same time the competence (experience stocks), the attitude and behavior (risk aversion, conservatism) and psychological processes (TMT cohesion and continuity). The TMT age and tenure are also indicators of Human Capital stability (Sveiby, 1997).

In order to understand the role of the TMT, we must distinguish between the effect of TMT demographic traits and that of the demographic heterogeneity. This latter reflects the diversity of TMT perspectives and points of view. It implies a greater ability of firms' creativity and adaptability. It stimulates the innovation but it can reinforce the affective conflicts which may harm the TMT harmony (Haynes and Hillman, 2010). The theoretical bedrock of this paper is the demographic approach. The research treats specifically the resources' effect (demographic attributes: TMT age and tenure) and the structural effect of TMT (TMT demographic heterogeneity: Jian et al., 2016).

\subsection{Board of Directors and Upper Echelons' Characteristics}

The relationship between the board structure and the TMT attributes may be studied according to two points of view: the contractual approach and the cognitive approach. The contractual approach assumes that the older TMT with longer tenure have a great power and they are characterized by a high level of entrenchment (Charreaux, 2000; Daily and Dalton, 1997; Morck et al., 1990; Zerni et al., 2010). In addition, the homogeneous TMT are more powerful than the heterogeneous ones since the homogeneity increases teamwork and consensus (Keck, 1997). These assumptions have been overturned by the cognitive theory that asserts that the older managers are not opportunists. Thus, the age and the seniority are synonyms of competence and skill (Human Capital Theory, Positive Entrenchment Theory). Also, the homogeneity of the managers' coalition is not systematically injurious (Castanias and Helfat, 1992; Garvey and Swan, 1994). In fact, the homogeneity reflects the solidarity and the coherence of the TMT (Carpenter, 2004). Furthermore, the homogeneity facilitates the decision-making process particularly for the firms operating in a competitive environment (Murray, 1989).

\subsection{Board Composition and TMT Characteristics}

According to the agency theory, the managers who benefit from a dual position have a great power. They are able to impose their choice and to pursue their self interests. By contrast, the theory of normal succession assumes that the duality allows a better strategic decision and does not systematically harmful (Vancil, 1987).

Also, the agency theory asserts that the small boards are more powerful. Therefore, the smaller boards tend to recruit younger and more heterogeneous group of managers in order to avoid the opportunistic behavior of the rooted TMT (Yermack, 1996).

On the other hand, the agency theory advocates "the effectiveness of the outsiders" (Kaymak and Bektas, 2008; Osma, 2008). The outsiders present a triple advantage: the opening of prospects, the experience and the independence (Fama, 1980; Fama and Jensen, 1983). In this respect, Kosnik (1990) affirms that the outsiders are more likely than the insiders to perform the shareholders' interests by decreasing the TMT entrenchment. This will not be true if the boards are dominated by the managers ("the managerial hegemony hypothesis": Lin and Hsing, 1997).

Hypothesis 1: The TMT characteristics depend on the composition of firm's board of directors (Duality of CEO, size of board and percentage of outsiders). More specifically, the TMT of firms with smaller boards, not dual and dominated by the outsiders are younger, less tenured and more heterogeneous.

\subsection{Ownership Structure and TMT Characteristics}

Four factors may have an impact on the TMT characteristics: the presence of block holders, the managerial ownership, the outsiders' ownership and the institutional ownership.

According to the agency theory, the concentration of capital reflects the effectiveness of the board. Thus, the TMT entrenchment of firms which are individually controlled (including at least one block holder) is lower than that of managerial firms (the ownership is dispersed among a large number of owners) (Finkelstein and Hambrick, 1995; Shleifer and Vishny, 1997). 
Furthermore, the entrenchment theory assumes that the managers who possess bigger share capital have a great power. So, they can use their power to orient the firms' policies in the direction of their self interests. This is opposed by the theory of the interests' convergence (Salancik \& Pfeffer, 1980).

In other hand, the outsiders who have a great ownership are more attentive in controlling the managers (Filatotchev \& Bishop, 2002). Thus, they seem to be able to decrease the TMT entrenchment.

Finally, the institutional ownership is considered as an effective mean of governance (Gompers, Ishii, \& Metrick, 2003). According to the dominant "efficient control hypothesis", the institutional investors who are also block holders can limit the TMT power (Pound, 1988). This is not true if the institutional investors have business relationships with the managers ("strategic alignment assumption"). But the "institutions' myopia theory" attests that the institutional investors are a transitional shareholders who are looking for short-term profits (Bushee, 1998).

Thus, we expected (according to contractual theory) that the best governed firms (with more effective board) are chaired by the less entrenched TMT (who are younger, recent and heterogeneous).

Hypothesis 2: The TMT characteristics depend on the firm's ownership structure (ownership of block holders, institutional investors, managers and outsiders).

\subsection{Beyond the Contractual Approach}

The theoretical framework of the cognitive approach is based essentially on Stewardship Theory, Human Capital Theory, Resource and Competence Based Theory, Positive Entrenchment Perspective and Power Circulation Model.

The Stewardship Theory supposes that managers act as responsible stewards of the assets they control. This theory is an alternative view of agency theory, in which managers are assumed to act in their own self interests at the expense of shareholders (Barney \& Hesterly, 2008, Davis et al., 1997, Donaldson \& Davis, 1991). According to the stewardship theory, the insiders exercise effective control on the managers because they have easy access to crucial information and they know deeply the company conditions and partners. In addition, the CEO who are at the same time chairman of the board, are not necessarily opportunists. On the contrary, they may be able to improve decision quality and to reassure the investors (via the common vision and the unity of supervision).

The Human Capital Theory developed by Becker (1964) is a modern extension of Adam Smith' explanation of wage differentials between employees. In practice, education, experience and tenure are the principal indicators of human capital.

The Resource Based Theory claims that the firm possesses a bundle of valuable resources which confer it a competitive advantage (Penrose, 1959; Rumelt, 1984; Wernerfelt, 1984). The key resource is the TMT competence. This latter is neither imitable nor substitutable (Barney, 2001; Grant, 1991).

The positive entrenchment perspective affirms that the entrenchment strategies are not destructive of the firm value. The entrenchment allows evading the short-term constraints imposed by the shareholders. Also, the entrenchment can provide the necessary serenity for managers to make long term investments and to increase their social networks which are beneficial for the firms (Castanias and Helfat, 1992; Garvey and Swan, 1994).

The power circulation model assumes that the managers may not hold for long period their power due to the obsolescence of their programs (Ocasio, 1994).

Moreover, the cognitive theory favors the board of great size because they generate cognitive conflicts and competitor political coalitions which are able to limit the CEO power. In this regard, the cognitive conflicts should develop the firms' organizational learning.

According to the cognitive approach, the TMT age and tenure are no longer considered as entrenchment vehicle but as TMT firm-specific human capital (Le et al., 2012). The entrenchment indicators can be regarded as vehicles of skills acquisition (Zingales and Rajan, 1998).

According to the stewardship theory, the oldest, tenured and homogenous TMT are not necessarily opportunists. Indeed, the relationship between the TMT and the shareholders is not hostile anymore but friendly. Their objectives are convergent. They aim to ameliorate the firms' competiveness. The origin of the conflicts between managers and shareholders can result from the difference of mental and cognitive perceptions: this difference can be translated into organizational learning: source of efficiency (O'Sullivan, 2000; Wirtz, 1999). The board is no longer supposed to control the managers but to support and help them. The board's role is to develop the human capital and to promote the best work conditions and not to constrain the managers (Tainio, 2001). The resource dependence theory suggests that boards are in a prime position to contribute to the strategic decision 
making process by providing links with external environments and access to valuable resources (Hillman \& Dalziel, 2003)

Thus, board composition and ownership structure which are supposed to reflect the board power; do not necessarily have a significant effect on the TMT characteristics. At this level, the managers' attributes are analyzed from the point of view of human capital and not from the entrenchment perspective. The governance effectiveness must not be perceived in terms of board characteristics but in terms of his contribution in developing human capital. Thus, it's not necessarily to fulfill the standards of good governance (in the sense of contractual approach) so that the company can enhance his human capital. The older, more tenured and homogenous TMT may have a high level of qualification which positively affects the companies' incomes. Also, the younger, recent and heterogeneous TMT may be preferred when referring to the cognitive considerations. In fact, these managers are generally more adventurous and innovators. So, they can provide a rich cognitive contribution for their firms.

In sum, the TMT tenure and heterogeneity have double edged cognitive implications. The long tenure may be associated with efficiency, reduced conflict, stronger social networks and greater knowledge of organizational resources (Chen, 2011). In the same time, the longer tenure has some negative effects like the statuo quo, the passive decision making and the disconnection from the outside sources of information (Chen et al., 2010). On the other hand, compared to older managers who are less risk oriented and more greatly concerned with financial and carrier security, the younger managers are associated with better learning ability and reasoning memory (Hermann \& Datta, 2005). Also and regarding the cognitive considerations, heterogeneity enhances cognitive resources, problem solving capacity and ability to change but may increase potential conflict and slows down decision making (Keck, 1997).

Based on the presumptions of the cognitive theory, we can issue our third hypothesis:

Hypothesis 3: The TMT characteristics are not necessarily related to the board effectiveness (in the contractual meaning).

\section{Research Methodology and Results}

To determine the effect of the board on the TMT characteristics, we propose to employ a quantitative approach that consists in two stages: First the K-Means Clusters are used to get homogeneous groups of TMT starting with their demographic features. Second a discriminating analysis is performed by regressing the discrete variable generated by the typology (in the first step) on the variables of governance (Groups of TMT $=f$ (Variables of governance). The data relate to 274 Most Admired American firms (Note 1)

Table 1 describes the firms' sectors and Table 2 presents the variables used in the analysis.

Table 1. Sectors of activities of firms

\begin{tabular}{llll}
\hline Sector & Number of firms & Percentage & Cumulative Percentage \\
\hline Basic Materials & 128 & 5,8 & 5,8 \\
Conglomerates & 296 & 13,5 & 19,3 \\
Consumer goods & 224 & 10,2 & 29,6 \\
Healthcare & 552 & 25,2 & 54,7 \\
Industrial Goods & 680 & 31,0 & 85,8 \\
Technology & 312 & 14,2 & 100,0 \\
Total & 2192 & 100,0 & \\
\hline
\end{tabular}

It's clear that the industrial goods sector is the most frequent, then come the healthcare and the technology sectors. 
Table 2. Variables of the study

\begin{tabular}{|c|c|}
\hline Variables & Measures \\
\hline \multicolumn{2}{|l|}{ Dependent Variables: TMT Attributes } \\
\hline \multicolumn{2}{|l|}{ Demographic characteristics } \\
\hline & Average TMT Age \\
\hline & Average TMT Tenure in current position \\
\hline & Average TMT Tenure in the firm \\
\hline \multicolumn{2}{|l|}{ Demographic Heterogeneity } \\
\hline & Heterogeneity of age in the TMT (age max - age min) \\
\hline & Heterogeneity of tenure (in current position) in the TMT \\
\hline & Heterogeneity of tenure (in firm) in the TMT \\
\hline \multicolumn{2}{|l|}{ Independent Variables : Board Characteristics } \\
\hline \multicolumn{2}{|l|}{ Board Composition } \\
\hline Board Size & Number of directors in the board \\
\hline Duality (Binary variable) & $=1$ if the chairman of the board is the $\mathrm{CEO}$ and $=0$ otherwise \\
\hline Percentage of outsiders in the board & Number of outsiders / Board Size \\
\hline $\begin{array}{l}\text { Percentage of majority individual shareholders in the } \\
\text { board }\end{array}$ & Number of majority individual shareholders / Board Size \\
\hline Percentage of institutional shareholders in the board & Number of institutional shareholders / Board Size \\
\hline \multicolumn{2}{|l|}{ Ownership Structure } \\
\hline Outsiders' ownership & Number of shares held by the outsiders / Total number of shares in circulation \\
\hline Managerial ownership & $\begin{array}{l}\text { Number of shares held by the managers and directors / Total number of shares in } \\
\text { circulation }\end{array}$ \\
\hline $\begin{array}{l}\text { Majority ownership (Majority shareholders ownership } \\
\text { exceeds 5\%) }\end{array}$ & $\begin{array}{l}\text { Number of shares held by the individual majority investors / Total number of shares in } \\
\text { circulation }\end{array}$ \\
\hline Institutional ownership & $\begin{array}{l}\text { Number of shares held by the institutional investors / Total number of shares in } \\
\text { circulation }\end{array}$ \\
\hline
\end{tabular}

\section{Step 1: Results of Non Hierarchical Classification (K - Means Clusters)}

The K-Means Clusters is one of the non hierarchical typology. It is suitable for the large samples $(>200$ observations). It is faster and more economic than the hierarchical classification. In general, the objective of the typology is to classify the TMT in homogeneous groups starting with a set of metric variables (demographic characteristics). The typology provides groups of TMT with similar demographic attributes. Thus, it will be possible to create a new qualitative variable indicating for each TMT its group membership. This new variable will be the dependent variable in our later discriminating analysis.

With reference to the demographic attributes of TMT (age, tenure in the current position and in the firm) a classification into dynamic groups yields the results indicated in table 3 and 4.

Table 3. Final cluster centers

\begin{tabular}{lll}
\hline & Cluster & \\
\hline Age & $\mathbf{1}$ & $\mathbf{2}$ \\
Tenure in current position & 52,7 & 55,5 \\
Tenure in firm & 3,0 & 6,7 \\
Number of cases & 8,3 & 21,0 \\
\hline
\end{tabular}

Table 4. ANOVA

\begin{tabular}{|c|c|c|c|c|c|c|}
\hline & \multicolumn{2}{|l|}{ Cluster } & \multicolumn{2}{|l|}{ Error } & \multirow[t]{2}{*}{$F$} & \multirow[t]{2}{*}{ Signification } \\
\hline & Mean Square & $D F$ & Mean Square & $D F$ & & \\
\hline Age & 2729,71 & 1 & 16,76 & 2190 & 162,91 & 0,00 \\
\hline Tenure in current position & 4720,41 & 1 & 10,49 & 2190 & 449,99 & 0,00 \\
\hline Tenure in firm & 55883,18 & 1 & 13,48 & 2190 & 4146,59 & 0,00 \\
\hline
\end{tabular}


The algorithm converged and led to the emergence of two classes on the basis of the three demographic attributes of managers. This algorithm has significantly contributed to the typology (according to the table 4 of the ANOVA). Table 3 shows that the $1^{\text {st }}$ class includes the younger and the less tenured managers while the older managers with a longer tenure belong to the $2^{\text {nd }}$ class.

The same method of classification is adopted but this time we started with the demographic heterogeneity attributes (heterogeneity in terms of the age, tenure in the current position and tenure in the firm). The TMT are then classified into two main classes: the $1^{\text {st }}$ class includes more heterogeneous TMT than the second (Table 5). Table 6 shows the relevance of variables used.

Table 5. Final cluster centers

\begin{tabular}{|c|c|c|}
\hline & \multicolumn{2}{|c|}{ Cluster } \\
\hline & 1 & 2 \\
\hline Heterogeneity of the age (1) & 17 & 14 \\
\hline Heterogeneity of tenure in the post (2) & 13 & 6 \\
\hline Heterogeneity of tenure in firm (3) & 27 & 10 \\
\hline Number of cases & 598 & 1594 \\
\hline
\end{tabular}

Table 6. ANOVA

\begin{tabular}{lllllll}
\hline & Cluster & & Error & F & Signification \\
\hline & Mean square & DF & Mean square & DF & & \\
$(1)$ & 4591,34 & 1 & 37,29 & 2190 & 123,11 & 0,00 \\
$(2)$ & 22445,82 & 1 & 40,85 & 2190 & 549,48 & 0,00 \\
$(3)$ & 132656,05 & 1 & 31,61 & 2190 & 4196,68 & 0,00 \\
\hline
\end{tabular}

We suggest, then, to create two new qualitative variables that indicate the group membership of each TMT. The $1^{\text {st }}$ variable reflects the managers' experience and the second one their level of heterogeneity. These two variables are named respectively "exp" and "het". The former takes the value 1 if the TMT belongs to class 1 of the first classification and takes the value of 2 otherwise. Similarly, "het" takes the value 1 if the TMT belongs to the class 1 resulting from the second classification and takes the value 2 otherwise.

Finally, we proceeded to create a third interactive discrete variable named "exphet" which is the product of the two qualitative variables resulted from the classifications previously undertaken ("exp" and "het"). Evidently "exphet" presents three modalities: 1,2 or 4 . The $1^{\text {st }}$ class corresponds to the younger, more recent and heterogeneous TMT. The $4^{\text {th }}$ comprises the older, more tenured and homogeneous one while the $2^{\text {nd }}$ includes the moderate values.

\section{Step 2: Results of Discriminating Analysis}

The fundamental principle of the discriminating analysis is to regress the qualitative variable generated by the typology ("exphet") on the quantitative variables of governance. It demonstrates the board characteristics which have a discriminating power: in other terms which maximize the separation between the groups of TMT.

We will present the discriminating analysis outputs which used the synthetic variable "exphet" as an endogenous variable and the variables of governance as descriptors.

First and in order to determine the discriminating variables, equality tests of Mean scores between the three groups are used (Table 7). 
Table 7. Tests of equality of group means

\begin{tabular}{|c|c|c|c|c|c|}
\hline Board characteristics \& Ownership Structure & Wilks'Lambada & $F$ & $d f 1$ & $d f 2$ & Sig \\
\hline Board Size & 0,99 & 3,53 & 2 & 2189 & 0,03 \\
\hline Duality & 1,00 & 0,39 & 2 & 2189 & 0,67 \\
\hline Percentage of outsiders in the board & 0,99 & 6,33 & 2 & 2189 & 0,00 \\
\hline Percentage of majority individual shareholders in the board & 0,98 & 23,64 & 2 & 2189 & 0,00 \\
\hline Percentage of institutional shareholders in the board & 1,00 & 0,03 & 2 & 2189 & 0,97 \\
\hline Outsiders' ownership & 0,99 & 2,38 & 2 & 2189 & 0,09 \\
\hline Managerial ownership & 0,981 & 21,45 & 2 & 2189 & 0,00 \\
\hline Majority ownership & 0,99 & 15,94 & 2 & 2189 & 0,00 \\
\hline Institutional ownership & 1,00 & 0,52 & 2 & 2189 & 0,59 \\
\hline
\end{tabular}

Table 7 shows that most of the board characteristics (regardless of duality and the presence of institutional investors in the board and in the capital) play a key role in discriminating between the different classes and therefore in selecting the demographic attributes of TMT.

In order to identify the characteristics of the different groups of TMT, we resorted to the descriptive statistics of the predictor discriminating variables (incorporated in Table 8).

Table 8. Univariate statistics for each group

\begin{tabular}{|c|c|c|c|}
\hline & & Mean & Standard Error \\
\hline \multicolumn{4}{|c|}{ "exphet" } \\
\hline \multicolumn{4}{|l|}{1} \\
\hline & Outsiders' Percentage & ,79 &, 10 \\
\hline & Majority shareholders percentage (individual) & ,06 &, 10 \\
\hline & Managerial ownership &, 11 &, 14 \\
\hline & Majority ownership & ,08 &, 14 \\
\hline \multicolumn{4}{|c|}{2} \\
\hline & Size board & 11,24 & 2,91 \\
\hline & Outsiders' Percentage &, 80 & ,09 \\
\hline & Majority ownership & 04 &, 11 \\
\hline \multicolumn{4}{|c|}{4} \\
\hline & Size board & 10,83 & 2,58 \\
\hline & Outsiders' Percentage &, 77 &, 12 \\
\hline & Majority shareholders percentage (individual) &, 049 &, 10 \\
\hline & Outsiders' ownership & ,25 & ,25 \\
\hline & Managerial ownership & ,09 &, 13 \\
\hline & Majority ownership &, 07 &, 14 \\
\hline
\end{tabular}

\section{Discussion}

\subsection{Comparison between Class 1 and the Other Two Classes (2 and 4)}

According to the descriptive statistics, it seems that class 1 (the younger, less tenured and heterogeneous TMT) compared to the other classes ( 2 and 4 ) is characterized by:

- A more reduced size of board

- A more noticeable presence of outsiders and majority investors

- A more pronounced ownership of the outsiders, managerial ownership and majority ownership.

We conclude that class 1 is the best governed. In other words, the less entrenched TMT run the firms which correspond to the standards of good governance as determined by the contractual theory. 
We can also note the non-discriminating role of duality and institutional investors which seem to be inactive in the choice of managers. This contradicts the assumption of activism and the effective control of the institutional investors (Pound, 1988). In addition, the results show the neutral effect of separating the functions of the CEO and the chairman of the board on the TMT demographic characteristics.

Apart from these three parameters, all the other mechanisms of governance are proved to be discriminating. The relevant presence of outsiders in the board and in the capital seems to be one of the levers that reduce the large scale of the managers' power $(F=6,33 ; F=2,38 ; p=0)$.

A smaller size of the directors' board is associated with a less powerful TMT (younger, less tenured and heterogeneous: $\mathrm{F}=3,53 ; \mathrm{p}<0,05$ ). This corroborates the agency theory ideas which privileged the small board because they are more vigilant in the control and they involve lower coordination expenses.

The majority shareholders have a significant explanatory power $(\mathrm{F}=23,64 ; \mathrm{F}=15,94 ; \mathrm{p}<0,01)$. The Block holders seem to intervene seriously in choosing the TMT. They are more inclined to promote less entrenched managers (Jensen and Meckling, 1976; Shleifer and Vishny, 1986).

Finally, the ownership of directors and managers has a discriminating role in favor of the less powerful TMT, which support to the theory of convergence of interests $(\mathrm{F}=21,45 ; \mathrm{p}<0,01)$. This theory stipulates that the managers who invest in the capital tend to maximize the wealth of investors since they themselves make a profit.

According to empirical results, we can confirm $\mathrm{H}_{1}$ and $\mathrm{H}_{2}$ which assume that the way how to govern firms has an impact on the demographic features of the managers, and that the more efficient the board of the firm is, the lower the chance of the TMT would be to strengthen their position. The board in a firm regarding better governance may consider choosing TMT who are younger, heterogeneous and have shorter tenures because these TMT are easier to control (Paquerot, 1997).

However, this conclusion must be carried out with vigilance because these results did not have a great confirmatory power since they are derived from general trends based on descriptive and exploratory statistics. In addition, we do not assume that class 1 corresponds to the standards of good governance while the other classes do not but we pointed out that class 1 seems to be the most consistent as it has characteristics which head towards the right direction.

Generally speaking and at this level, the results are consistent with the assumptions of the classical theory of agency. However, it is certainly unfair to reject categorically the ideas of cognitive approaches. It may be the case that the firms which afford better conditions of governance opt for TMT of class 1 for cognitive reasons and not for considerations of entrenchment as assumed by the agency theory. In fact, these boards prefer young, recent and heterogeneous TMT because they are more innovative, open and flexible.

\subsection{Comparison between Class 2 and Class 4}

The arguments advanced by the contractual theory of governance explain perfectly the results which are related to the transition from group 1 to groups 2 and 4 . But they are unable to explain that from group 2 to group 4 . Seemingly, the relationship between governance and human capital is not monotonous and it is not linear since the best governed firms correspond to the extreme cases (group 1 and 4) while the moderately powerful TMT are associated with the lowest level of governance. The comparison between class 2 and class 4 supports rather the cognitive theories. Thus, the best controlled firms can allow and even enhance higher levels of entrenchment and managers' power (oldest, tenured and homogenous TMT).

In sum, the theoretical arguments of both the contractual and cognitive approaches may be used to interpret our results. The effect of the board efficiency on the degree of managers' entrenchment seems to be of quadratic form. Firstly (the transition from class 2 to 4), the ideas of the cognitive, human capital, stewardship and the positive entrenchment theories may be appropriate. Secondly (the transition from class 1 to class 2 and 4), however, the arguments of the detrimental entrenchment theory prevail.

\section{Conclusion}

The objective of this work is to apprehend the effect of the directors' board characteristics and the firms' ownership structure on the TMT characteristics.

To do this, an empirical approach of two stages has been conducted. Firstly, we extract via the clustering method, three groups of TMT which have different demographic attributes. Secondly, we use a discriminating analysis to determine the main characteristics of the board which influence the choice of the TMT features. The $1^{\text {st }}$ step leads to three different classes: a first class which comprises the youngest, less tenured and heterogeneous TMT, a second class that consists in average values and a third class which includes to the oldest and most 
homogeneous and tenured TMT. The discriminating analysis revealed the significant effect of governance variables (excluding the duality and institutional investors) in the separation between these three groups already identified. A review of the descriptive statistics revealed the following trend: the more the firms comply with the principles of good governance (according to the contractual theory), the more their TMT would be young, recent and heterogeneous. Thus, the assumptions of the classical agency theory of entrenchment seem to be valid. But a more detailed analysis of our results highlights the probable "non-linearity" of the effect of governance on TMT attributes. Therefore, we must also pay a close attention to the cognitive considerations to understand the TMT issue. The results confirm the third hypothesis that assumes that the TMT demographic traits are not tied systematically to the board effectiveness. Only, the contractual approach failed to explain the TMT structure. Whereas, the strategic and the cognitive arguments can provide undeniable lesson to understand the TMT issue.

\section{Research Contribution}

The difficulty and at the same time the contribution of this paper that it has considered two fields of research: the financial literature (the "corporate governance" concept) and the strategic management (the "TMT" issue). Then, this paper has emphasized the relevance of the cognitive approach assumptions. Also, it proposed a relationship of quadratic form between the governance structure and the TMT attributes.

The main contribution of this paper for corporate governance and management is that: the board choice of TMT is not systematically based on entrenchment arguments but also on cognitive considerations. In other words, independently of governance efficiency according to disciplinary approach criteria, the board may prefer the more tenured and homogenous managers because they are more efficient and united in competitive environment (Keck, 1997). Also, the board may be inclined to favor the younger and heterogeneous managers who are less entrenched with more knowledge and skills to solve complex problems in dynamic environment (Castro et al., 2009, Li and Harrison, 2008). In fact, the more diverse TMT have a broader range of perspectives and they are able to access to external resources and to enhance the capabilities in dealing with complexity and ambiguity (Haynes and Hillman, 2010).

\section{Research Limits}

However, this paper presents certain limits. In spite of the obvious contribution of the demographic approach, several authors consider it as limited and unable to measure with precision the TMT competence. Measures focusing on the process and the cognitive models may be more reliable in this respect (Markoczy, 2000; Carpenter et al., 2004; Oppong, 2014). Therefore, it would be interesting to enrich the measurement of human capital by considering other demographic attributes (such as education, experience and functional specialty). Also, adding other governance characteristics can provide better insights in this matter. Furthermore in the future researches, the results will be more reliable if we introduce some moderating factors such as the type of environment or the firm objective and strategy in dealing with the relationship between the TMT attributes and the board characteristics.

\section{References}

Alchian, A. A., \& Demsetz, H. (1972). Production, Information Costs and Economic Organization. American Economic Review, 62(5), 777-795.

Barney, J. B. (2001). Is the Resource-Based Theory a Useful Perspective for Strategic Management Research? Academy of Management Review, 26(1), 41-56.

Barney, J. B., \&Hesterly, W. S. (2008). Strategic Management and Competitive Advantages.Pearson Prentice Hall.

Becker, G. S. (1964). Human Capital: A Theoretical and Empirical Analysis, with Special Reference to Education. Chicago: University of Chicago Press.

Beckman, C. M., \& Burton, M. D. (2008). Founding the Future: Path Dependence in the Evolution of Top Management Teams from Founding to IPO. Organization Science, 19(1), 3-24. https://doi.org/10.1287/orsc.1070.0311

Beckman, C. M., Burton, D., \& O'Reilly, C. (2007). Early Teams: The Impact of Team Demography on VC Financing and Going Public. Journal of Business Venturing, 22, 147-173.

Berle, A., \& Means, G. (1932). The Modern Corporation and Private Property. New York: Macmillan.

Bontis, N. (1998). Intellectual Capital: an Exploratory Study that Develops Measures and Models. Management Decision, 36(2), 63-76. 
Bushee, B. (1998). Influence of Institutional Investors on Myopic R\&D Investment Behavior. The Accounting Review, 73(3), 305-333

Buyl, T., Boone, C., Hendriks, W., \& Matthyssens, P. (2011). Top Management Team Functional Diversity and Firm Performance: The Moderating Role of CEO Characteristics.Journal of Management Studies, 48, 151-177. https://doi/10.1111/j.1467-6486.2010.00932.

Carpenter, M. A., Geletkanycz, M. A., \& Sanders, G. W. (2004). Upper Echelons Research Revisited: Antecedents, Elements, and Consequences of Top Management Team Composition. Journal o $f$ Management, 30(6), 749-778. https://doi/abs/10.1016/j.jm.2004.06.001

Castanias, R. P., \& Helfat, C. E. (1992). Managerial and Windfall Rents in the Market for Corporate Control. Journal of Economic Behavior and Organization, 18, 153-184. https://doi/abs/10.1177/014920630102700604

Castro, C. B., De La Concha, M. D., Gravel, J. V., \& Perinan, M. V. (2009). Does the team leverage the board's decisions?Corporate Governance: An International Review, 17, 744-761.

Certo, S. T., Lester, R. H., Dalton, C. M., \& Dalton, D. R. (2006). Top Management Teams, Strategy and Financial Performance: A Meta-Analytic Examination. Journal of Management Studies, 43(4).

Charreaux, G. (2000). Le conseil d'administration dans les théories de la gouvernance. La Revue du Financier, 217, 6-17.Retrieved from http://crego.u-bourgogne.fr/images/stories/wp/001201.pdf

Chen, H. L. (2011). Does Board Independence Influence the Top Management Team? Evidence from Strategic Decisions toward Internationalization. Corporate Governance: An International Review, 19(4), 334-350. https://doi.org/10.4236/jssm.2012.52018

Chen, H. L., Hsu, W. T., \& Huang, Y. S. (2010). Top management team characteristics, R\&D investment, and capital structure in the IT industry. Small Business Economics, 35, 319-330.

Daily, C. M., \& Dalton, D. R. (1997). CEO and Board chair roles held jointly or separately: Much ado about nothing? Academy of Management Executive, 11 (3), 11 - 20.

Daily, C. M., Certo, S. T., \& Dalton, D. R. (2000). A Decade of Corporate Women: Some Progress in the Boardroom. Strategic Management Journal, 20, 93-99. Retrieved from http://library.pcw.gov.ph/sites/default/files/decade\%20of\%20corporate\%20women.pdf

Davis, J. H., Schoorman, F. D., \& Donaldson, L. (1997). Toward a Stewardship Theory of Management. Academy of Management Review, 22, 20-47.

Donaldson, L., \& Davis, J. H. (1991). Stewardship theory or agency theory: CEO governance and shareholder returns. Australian Journal of Management, 16, 49-64. Retrieved from https://pdfs.semanticscholar.org/b226/d681d20fb646b147ecb3f452fb5de2269cb7.pdf

Fama, E., \& Jensen, M. C. (1983).Separation of Ownership and Control.Journal of Law and Economics, 26(2), 301-325. https://www.jstor.org/stable/1837292

Fama, E. (1980). Agency Problems and the Theory of the Firm. Journal of Political Economy, 88, 288-307.

Filatotchev, I., \& Bishop, K. (2002). Board Composition, Share Ownership, and Underpricing of U.K. IPO Firms. Strategic Management Journal, 23(10), 941-955. https://oi/10.1002/smj.269/

Finkelstein, S., \& Hambrick, D. C. (1995). The Effects of Ownership Structure on Conditions at the Top. Strategic Management Journal, 16(3), 175-193. https://doi.org/10.1002/smj.4250160304

Finkelstein, S., \& Hambrick, D. C. (1996). Strategic Leadership: Top Executives and Their Effects on Organizations. West Publishing Company, 22(3), 802-805. Retrieved from http://cteseerx.ist.psu.edu/viewdoc/download?doi=10.1.1.214.3289\&rep=rep1\&type=pdf

Finkelstein, S., Hambrick, D. C., \& Cannella, A. A. (2009). Strategic Leadership: Theory and Research on Executives, Top Management Team, and Boards. New York: Oxford University Press.

Garvey, G. T., \& Swan, P. L. (1994). The Economics of Corporate Governance beyond the Marshallian Firm.Journal of Corporate Finance, 1(2), 139-174. Retrieved from https://EconPapers.repec.org/RePEc:eee:corfin:v:1:y:1994:i:2:p:139-174

Gompers, P., Ishii, J., \& Metrick, A. (2003). Corporate Governance and Equity Prices. Quarterly Journal of Economics, $\quad 118, \quad 107-155 . \quad$ Retrieved from https://pdfs.semanticscholar.org/9043/87fc8f4254ee70acebb7f20f060ffb114ebf.pdf 
Grant, R. M. (1991). The Resource-Based Theory of Competitive Advantage: Implications for Strategy Formulation. California Management Review, 33(3), 114-135.

Hambrick, D. C., \& Mason, P. A. (1984). Upper Echelons: The Organization as a Reflection of its Top Managers. Academy of Management Review, 9(2), 193-206.https://doi.org/10.2307/258434

Haynes, K. T., \& Hillman, A. (2010). The effect of board capital and CEO power on strategic change. Strategic Management Journal, 31, 1145-1163. https://doi.org/10.1002/smj.859

Herrmann, P., \& Datta, D. K. (2005). Relationships between top management team characteristics and international diversification: An empirical investigation. British Journal of Management, 16, 69-78. https://doi.org/10.1111/j.1467-8551.2005.00429.x

Hillman, A. J., \& Dalziel, T. (2003). Boards of directors and firm performance: Integrating agency and resource dependence perspectives. Academy of Management Review, 28, 383-396. https://doi.org/10.2307/30040728

Hitt, M. A., Bierman, L., Uhlenbmck, K.,\& Shimizu, K. (2006). The Importance of Resources in the Internationalizadon of Professional Service Firms: The Good, The Bad and The Ugly. Academy of Management Joumal, 49, 1137-1157.

Hogan, R., \& Kaiser, B. R. (2005). What We Know About Leadership. Review of General Psychology, 9(2), $169-180$

Jaw, Y., \& Lin, W. (2009). Corporate Elite Characteristics and Firm's Internationalization: CEO-Level and TMT-Level Roles. The International Journal of Human Resource Management, 20(1), 220-233. https://doi.org/10.1080/09585190802528797

Jensen, M. C., \& Meckling, W. H. (1976). Theory of the Firm: Managerial Behavior, Agency Costs and Ownership Structure. Journal of Financial Economics, 3, 305-360. https://doi.org/10.1016/0304-405X(76)90026-X

Jian, H., \& Weining, L. (2016). Study on TMT Heterogeneity's Effects on Corporate Performance from the Perspective of Leadership Structure. Open Journal of Business and Management, 4, 148-156. https://dx.doi.org/10.4236/ojbm.2016.41017

Karami, A., Analoui, F., \& Kakabadse, K. (2006). The CEOs' Characteristics and their Strategy Development in the UK SME Sector. The Journal of Management Development, 25(3/4), 316. https://doi.org/10.21315/aamj2017.22.1.2

Kaymak, T., \& Bektas, E. (2008). East meets West? Board characteristics in an emerging market: Evidence from Turkish banks. Corporate Governance: An International Review, 16, 550-561.

Keck, S. L. (1997). Top management team structure: Differential effects by environmental context. Organization Science, 8, 143-156.https://doi.org/10.1287/orsc.8.2.143

Kosnik, R. D. (1990). The Effect of Board Demography and Directors Incentives on Corporate Greenmails Decisions. Academy of Management Journal, 33, 106-128.

Laszlo, T., Scott, G., \& Gerard, G. (2015). Rethinking Governance in Management Research. Academy of Management Journal,1015(1), 1-9. https://doi.org/10.5465/amj.2014.4006

Le, S. A., Kroll, M., \& Walters, B. A. (2012). The Influence of Board Composition on Top Management Team Industry- and Firm-Specific Human Capital in Young IPO Firms. Journal of Managerial Issues,24(4), $412-432$

Li, J., \& Harrison, J. R. (2008). National culture and the composition and leadership structure of boards of directors. Corporate Governance: An International Review, 16, 375-385. https://doi.org/10.1111/j.1467-8683.2008.00697.x

Lin, W., \& Hsing, Y. (1997). The Determinants of CEO's Compensation in Retailing.Management Research News, 20(6), 43-49.

Markoczy, L. (2000). From Demography to Cognitive Measurements. Thesis, Anderson Graduate School of Management: University of California.

Marvel, M. R., Davis, J. L., \& Sproul, C. R. (2016). Human Capital and Entrepreneurship Research: A Critical Review and Future Directions. Entrepreneurship: Theory and Practice, 40(3), 599-626. https://doi.org/10.1111/etap.12136 
Mihalache, O. R., Jansen, J. J., Van Den Bosch, A., \& Volberda, H. W. (2014). Management Team Shared Leadership and Organizational Ambidexterity: A Moderated Mediation Framework. Strategic Entrepreneurship Journal, 8, 128-148. https://doi.org/10.1002/sej.1168

Morck, R., Shleifer, A., \& Vishny, R. W. (1990). Do managerial objectives drive bad acquisitions. Journal of Finance, 45(1), 31-48.

Murray, A. (1989). Top Management Group Heterogeneity and Firm Performance. Strategic Management Journal, 10, 125-141.https://doi.org/10.1002/smj.4250100710

O'Sullivan, M. (2000). The Innovative Enterprise and Corporate Governance. Cambridge Journal of Economics, 24(4), 393-416. https://doi.org/10.1093/cje/24.4.393

Ocasio, W. (1994). Political Dynamics and the Circulation of Power: CEO Succession in US Industrial Corporations. Administrative Science Quarterly, 39(2), 285-312. https://dx.doi.org/10.2307/2393237

Oppong, S. (2014). Upper Echelons Theory Revisited: The Need for a Change from Causal Description to Casual Explanation.Management,19(2), 169-183.

Osma, B. G. (2008). Board independence and real earnings management: The case of R\&D expenditures. Corporate Governance: An International Review, 16, 116-131.

Palacios, M. (2015). Human capital as an asset class implications from a general equilibrium model. Review of Financial Studies, 28 (4), 978-1023. https://doi.org/10.1093/rfs/hhu073

Paquerot, M. (1997). Stratégies d'Enracinement des Dirigeants, Performance de la Firme et Structures de Contrôle. In Economica (Ed.), Le Gouvernement des Entreprises.

Penrose, E. T. (1959). The Theory of the Growth of the Firm. New York: John Wiley

Peterson, R. S., Martorana, P. V., Smith, D. B., \& Owens, P. D. (2003). The Impact of Chief Executive Officer Personality on Top Management Team Dynamics: One Mechanism by Which Leadership Affects Organizational Performance. Journal of Applied Psychology, 88(5), 795-808. https://doi.org/10.1037/0021-9010.88.5.795

Pound, J. (1988). Proxy Contests and the Efficiency of Shareholder Oversight. Journal of Financial Economics, 20(1\&2), 237-265. Retrieved from http://www.sciencedirect.com/science/article/pii/0304-405X(88)90046-3

Rumberger, R. W. (1987). The impact of surplus schooling on productivity and earning. Journal of Human Resources, 22(1), 24-50. https://doi.org/10.1111/j.1468-232X.1991.tb00786.x

Rumelt, R. P. (1984). Towards a Strategic Theory of the Firm. In R. B. Lamb (Ed.), Competitive Strategic Management (pp. 556-570). Englewood Cliffs, NY, Prentice Hall. https://doi.org/10.4236/ib.2011.32020

Salancik, G., \& Pfeffer, J. (1980). Effects of Ownership and Performance on Executive Tenure in US Corporations. Academy of Management Journal, 23, 653-664.

Shleifer, A., \& Vishny, R. W. (1986).Large Shareholders and Corporate Control. Journal of Political Economy, 94(3), 461-489. https://links.jstor.org

Shleifer, A., \& Vishny, R. W. (1997). A Survey of Corporate Governance. Journal of Finance, 52, 737-783.

Sveiby, E. 1997.The Intangible Asset Monitor. Journal of Human Resources and Cost Accounting, 2(1), 73-97.https://doi.org/10.1108/eb029036

Tainio, R. (2001). The Role of Boards in Facilitating or Limiting Learning in Organizations. In M. Dierkes et al. (Eds.), Handbook of Organizational Learning and Knowledge. Oxford, Oxford University Press.

Taylor, B. (2003). Board leadership: Balancing entrepreneurship and strategy with accountability and control. Corporate Governance, 3(2), 3. https://doi.org/10.1111/j.1467-8551.2005.00446.x

Tsang, M. C. (1987). The impact of underutilization of education on productivity: A case study of the US companies. Economics of Education Review, 6(3), 239-254. https://doi.org/10.1016/0272-7757(87)90003-3

Vancil, R. (1987). Passing the Baton: Managing the Process of CEO Succession. Harvard Business School Press. https://doi.org/10.1002/hrm.3930270210

Wernerfelt, B. (1984). The Resource-Based View of the Firm. Strategic Management Journal, 5(2), 171-180. https://doi.org/10.1002/mj.4250050207

Williamson, O. E. (1985). The Economic Institutions of Capitalism. New York: Free Press. 
Wirtz, P. (1999). Le dirigeant: intendant fidèleou agent opportuniste? Evolution institutionnelle, schémasmentaux et gouvernement des entreprises: le cas de krupp - Thyssen. Finance Contrôle Stratégie, 2(1), 117-143.

Yermack, D. (1996). Higher Market Valuation of Companies with a Small Board of Directors. Journal of Financial Economics, 40(2), 185-211.

Zerni, M., Kallunki J. P., \& Nilsson, H. (2010). The Entrenchment Problem, Corporate Governance Mechanisms, and Firm Value. Contemporary Accounting Research, 27(4), 1169-1206.

Zingales, L., \& Rajan, R. (1998). Power in a Theory of the Firm. Quarterly Journal of Economics, 113(2), 387-432. https://doi.org/10.1162/003355398555630.

\section{Note}

Note 1.It is a random sample. It is constituted by the Most Admired American Firms of "Fortune Magazine" for which all data are available.

\section{Copyrights}

Copyright for this article is retained by the author(s), with first publication rights granted to the journal.

This is an open-access article distributed under the terms and conditions of the Creative Commons Attribution license (http://creativecommons.org/licenses/by/4.0/). 